\title{
Uterine DNA synthesis and cell proliferation during early decidualization induced by oil in mice
}

\author{
R. M. Das and L. Martin \\ Department of Hormone Physiology, The Endocrine Group, The Imperial Cancer Research Fund, \\ Lincoln's Inn Fields, London WC2A 3PX, U.K.
}

\begin{abstract}
Summary. $\left[{ }^{3} \mathrm{H}\right]$ Thymidine autoradiography was used to study cell proliferation during decidualization induced by intraluminal oil in ovariectomized mice treated with oestrogen and progesterone. Development of the decidual reaction involves two distinct populations of stromal cells. Periluminal cells start to synthesize DNA 11-15 h after instillation and by $17-20 \mathrm{~h}$, without dividing, differentiate into epithelioid decidual cells which continue to incorporate $\left[{ }^{3} \mathrm{H}\right]$ thymidine, presumably becoming polyploid. Cells peripheral to this zone also start to synthesize DNA between 11 and $15 \mathrm{~h}$, but at $18.5 \mathrm{~h}$ many have divided before differentiating. None of these dividing cells had been arrested in $\mathbf{G}_{2}$. The periluminal and peripheral cells do not appear to differ in their proliferative antecedents.
\end{abstract}

\section{Introduction}

There are several studies of cell proliferation during decidualization in pregnant rodents (Lobel, Levy \& Shelesnyak, 1967; Zhinkin \& Samoshkina, 1967; Galassi, 1968). The use of pregnant animals raises the problem of knowing when decidualization starts and can lead to confusion between hormone-induced stromal proliferation (Martin \& Finn, 1968) and that associated with the decidual response (see Zhinkin \& Samoshkina, 1967). We have therefore studied cell proliferation in the first $20 \mathrm{~h}$ of decidualization induced by the intrauterine instillation of arachis oil in hormone-treated ovariectomized mice. The hormone requirements for successful induction closely resemble those for blastocyst implantation (Finn, 1965, 1966, 1971).

\section{Materials and Methods}

Swiss Schneider mice, approximately 2 months old, were housed, ovariectomized and primed with oestrogen as described by Finn \& Martin (1972). Starting on the 3rd day after priming they received three once-daily s.c. injections of $1 \mathrm{mg}$ progesterone (B.D.H.) and $10 \mathrm{ng}$ oestradiol-17 $\beta$ (Organon Laboratories) in $0.05 \mathrm{ml}$ arachis oil at 11:00 h. On the $3 \mathrm{rd}$ day of treatment the mice were anaesthetized with tribromoethanol and the uterus was exposed by a dorsal incision; $5 \mu$ arachis oil were instilled into the left uterine horn through the ovarian tip 4-5 h after the last injection of hormones. The right horn was left untreated as a control. In the first experiment groups of mice were given an intraperitoneal injection of $40 \mu \mathrm{Ci}\left[{ }^{3} \mathrm{H}\right]$ thymidine (sp. act. $5 \mathrm{Ci} / \mathrm{mmol}$ : Radiochemical Centre, Amersham) at various times (Table 1) after oil instillation and were killed $1 \mathrm{~h}$ later.

Experiment 2 was to test whether any mitotic figures arose from cells which had remained in $\mathrm{G}_{2}$ after replicating their DNA during the predecidual period, and mice were killed $20 \mathrm{~h}$ after oil instillation and at various times after giving $\left[{ }^{3} \mathrm{H}\right]$ thymidine alone or with colcemid, which arrests mitosis at metaphase. Groups of 6 mice at 15 or $17.5 \mathrm{~h}$ after instillation were given $40 \mu \mathrm{Ci}$ [ ${ }^{3} \mathrm{H}$ ]thymidine with or without colcemid $(0.1 \mathrm{mg}$ s.c. in $0.1 \mathrm{ml}$ saline). Mice in an additional group each received $40 \mu \mathrm{Ci}\left[{ }^{3} \mathrm{H}\right]$ thymidine $1 \mathrm{~h}$ before autopsy at $20 \mathrm{~h}$.

Experiment 3 was to test whether primary decidual cells arose predominantly from cells that replicated their DNA during the immediate predecidual period. Each mouse was given an injection of $40 \mu \mathrm{Ci}\left[{ }^{3} \mathrm{H}\right]$ thymidine $15 \mathrm{~h}$ after the first and after the second of the progesterone/oestrogen injections 
which induced stromal cell proliferation (Finn \& Martin, 1969). Intraluminal oil was instilled as before and the mice were killed $48 \mathrm{~h}$ later when decidualization was well advanced.

At autopsy all uteri were fixed in Bouin's fluid and central areas of deciduomata were located by serial sectioning. Autoradiographs were prepared (Das, 1972) and stained with Cole's haematoxylin and eosin.

Labelling indices were determined on 400 cells/animal. Periluminal counts were confined to an antimesometrial arc of cells lying 10 deep immediately beneath the luminal epithelium and extending from a point mid-way between the meso- and antimeso-metrial poles of the lumen on one side to the corresponding point on the other. Mid-region counts were confined to a band of cells 10-15 deep lying about midway between the lumen and the myometrium and separated from the periluminal region (as defined above) by at least 10 cells. Up to $20 \mathrm{~h}$ after instillation no decidual cells are found in this area, whereas at $48 \mathrm{~h}$ most cells in this region have become decidual cells.

The proportions of labelled mitotic figures were determined on at least 100 mitotic figures per animal. Cells were considered to be labelled if they had 10 or more silver grains over the nucleus. Counts of mitotic figures were made on one section from each animal.

\section{Results}

Experiment 1. By $10 \mathrm{~h}$ after oil instillation the treated uteri showed marked stromal oedema (PI. 1, Fig. 1) compared with the uninjected controls (Pl. 1, Figs 2 and 4). Fibroblastic cells in the periluminal crescent remained densely packed but although they showed nuclear swelling and nucleolar enlargement (Pl. 1, Fig. 3) there was no increase in $\left[{ }^{3} \mathrm{H}\right]$ thymidine incorporation at this time (Table $1 ; \mathbf{P l} .1$, Figs 1 and 3). Cells in the periluminal region still appeared fibroblastic 14-15 $\mathrm{h}$ after stimulation but many were incorporating $\left[{ }^{3} \mathrm{H}\right]$ thymidine (Pl. 2, Figs 5 and 6; Table 1), and labelling indices ranged from 20 to $50 \%$. From 16 h onwards the periluminal cells continued to incorporate $\left[{ }^{3} \mathrm{H}\right]$ thymidine but became progressively more epithelioid with increasing amounts of cytoplasm and enlarged nuclei (Pl. 2, Fig. 7). At $20 \mathrm{~h}$ most uteri showed a well defined primary zone of enlarged decidual cells which were still incorporating $\left[{ }^{3} \mathrm{H}\right]$ thymidine (Pl. 2, Fig. 8). Over the whole period of observation no mitotic figures were observed in the periluminal zone (Table 1).

Outside the primary zone increased DNA synthesis was also first observed at $15 \mathrm{~h}$ (Table 1) but from $18 \cdot 5 \mathrm{~h}$ onwards many mitotic figures appeared, forming a distinct band around the primary zone

Table 1. DNA synthesis (mean \pm s.e.m.) in control and stimulated mouse uteri during decidualization induced by arachis oil

\begin{tabular}{|c|c|c|c|c|c|}
\hline \multirow{3}{*}{$\begin{array}{c}\text { Time after } \\
\text { stimulation (h) }\end{array}$} & \multirow{3}{*}{$\begin{array}{l}\text { No. of } \\
\text { mice }\end{array}$} & \multicolumn{3}{|c|}{ Labelling index $(\%)$} & \multirow{3}{*}{$\begin{array}{l}\text { No. of } \\
\text { stromal mitotic } \\
\text { figures/section in } \\
\text { stimulated horn }\end{array}$} \\
\hline & & \multirow{2}{*}{$\begin{array}{c}\text { Control horn } \\
\text { Periluminal }\end{array}$} & \multicolumn{2}{|c|}{ Stimulated horn } & \\
\hline & & & Periluminal & Mid-region & \\
\hline 0 & 5 & $2 \cdot 2 \pm 0.4$ & - & - & - \\
\hline 5 & 5 & $3.6 \pm 1.6$ & $5 \cdot 2 \pm 2 \cdot 4$ & - & - \\
\hline 10 & 5 & $3 \cdot 2 \pm 0.9$ & $1 \cdot 2 \pm 0.5$ & $0.4 \pm 0.2$ & - \\
\hline 11 & 6 & $2 \cdot 7 \pm 1 \cdot 0$ & $2 \cdot 2 \pm 1 \cdot 0$ & $6 \cdot 3 \pm 3 \cdot 2$ & - \\
\hline 15 & 5 & $7 \cdot 8 \pm 3 \cdot 0$ & $23.8 \pm 8.5$ & $23 \cdot 0 \pm 7 \cdot 1$ & 0 \\
\hline 16 & 5 & $6.6 \pm 2 \cdot 0$ & $27 \cdot 4 \pm 1 \cdot 0$ & $51 \cdot 4 \pm 8.0$ & $0.2 \pm 0.2$ \\
\hline $18 \cdot 5$ & 6 & $3 \cdot 5 \pm 1 \cdot 0$ & $41 \cdot 5 \pm 11 \cdot 0$ & $37.3 \pm 6.5$ & $31 \cdot 3 \pm 12 \cdot 0$ \\
\hline 20 & 5 & $7 \cdot 0 \pm 0.7$ & $48 \cdot 8 \pm 7 \cdot 2$ & $59.0 \pm 6.0$ & $22 \cdot 2 \pm 11 \cdot 2$ \\
\hline 21 & 5 & $5 \cdot 2 \pm 2 \cdot 0$ & $40 \cdot 0 \pm 3 \cdot 4$ & $27 \cdot 0 \pm 3 \cdot 0$ & $41 \cdot 0 \pm 5 \cdot 3$ \\
\hline
\end{tabular}


(Pl. 2, Fig. 7). This is similar to the arrangement observed by Finn \& Martin (1967) in mice late on Day 5 of pregnancy. Throughout the period of observation labelling indices in the control horn showed little change (Table 1).

Experiment 2 . When $\left[{ }^{3} \mathrm{H}\right]$ thymidine was given $1 \mathrm{~h}$ before autopsy only $1.5 \pm 0.6 \%$ (mean \pm s.e.m.) of mitotic figures were labelled. When $\left[{ }^{3} \mathrm{H}\right]$ thymidine and colcemid were given $2.5 \mathrm{~h}$ before autopsy, $16.4 \pm 3.0 \%$ of mitotic figures were labelled. [ ${ }^{3} \mathrm{H}$ ]Thymidine given alone $5 \mathrm{~h}$ before autopsy resulted in $99.0 \pm 0.4 \%$ of mitotic figures being labelled and the proportion rose to $99.8 \pm 0.2 \%$ when colcemid was given with the thymidine $5 \mathrm{~h}$ before autopsy. These results showed that almost all the dividing cells had been in S-phase $5 \mathrm{~h}$ previously.

Experiment 3. $\left[{ }^{3} \mathrm{H}\right]$ Thymidine-labelled cells were found in the periluminal and mid-regions of the stroma. Both areas were decidualized and had similar $\left[{ }^{3} \mathrm{H}\right]$ thymidine labelling indices.

\section{Discussion}

In the rat the primary decidual zone develops in an antimesometrial crescent of periluminal stromal cells (Krehbiel, 1937). Our results show that the same happens in the mouse.

The absence of mitotic figures in the primary zone during decidual differentiation and while $\left[{ }^{3} \mathrm{H}\right]$ thymidine incorporation continues supports the finding of Leroy (1974) that decidual cells are polyploid. It might be argued that cells in the primary zone replicate DNA in situ, migrate to the outer mitotic zone to divide, and return to the primary zone to differentiate. However, no mitotic figures were seen in any zone before $18.5 \mathrm{~h}$, by which time many primary-zone cells were well differentiated decidual cells. Furthermore, uteri from animals treated with colcemid at $17.5 \mathrm{~h}$ and autopsied at $20 \mathrm{~h}$ showed well developed mitosis-free zones of decidual cells surrounded by bands of arrested mitotic figures. Finally, the proportions of labelled mitotic figures indicate a probable $\mathrm{G}_{2}$ duration of at least $2.5 \mathrm{~h}$. We conclude, therefore, that there are two distinct populations of stromal cells: (1) cells in the primary zone which undergo DNA synthesis and, without dividing, differentiate into polyploid decidual cells, and (2) cells in the secondary zone which synthesize DNA and divide before differentiating.

Galassi (1968) gave pregnant rats $\left[{ }^{3} \mathrm{H}\right]$ thymidine during the period of hormone-induced proliferation that precedes decidualization and observed that labelling was confined to the periluminal crescent before decidualization and to the primary decidual zone afterwards. Because she saw no stromal mitotic figures until decidualization, Galassi suggested that decidual cells arose from a population arrested in $\mathrm{G}_{2}$. Later workers observed uterine mitotic activity in the predecidual periluminal stroma in pregnant and pseudopregnant rats (Leroy \& Galand, 1969; Chaudhury \& Sethi, 1970; Tachi, Tachi \& Lindner, 1972; Marcus, 1974) but these observations did not exclude the possibility that cells dividing during decidualization had been arrested in $\mathrm{G}_{2}$; the present results do.

In rats, hormone-induced stromal mitosis is confined to the immediate periluminal cells (Tachi et al., 1972; Clark, 1973). There is therefore close correspondence between the zones of hormonally induced proliferation and primary decidualization. This suggests that primary decidual cells might derive exclusively from cells which had divided as a result of hormonal stimulation. In the mouse, however, the two zones do not correspond because hormone-induced proliferation, while most intense periluminally, extends far into the stroma (Finn \& Martin, 1967; Martin \& Finn, 1968; Martin, Finn \& Trinder, 1973). On the other hand, cells proliferating under hormonal stimulation might later migrate into the primary decidual zone. The results of Exp. 3 indicate that this does not happen and suggest that cells in the primary decidual zone do not differ in their proliferative antecedents from those in the secondary zone. The difference in differentiative behaviour presumably arises purely as a result of position.

We wish to thank Gail Trinder for preparing the sections and autoradiographs and Lorna Lee for technical assistance. 


\section{References}

Clark, B.F. (1973) The effect of oestrogen and progesterone on uterine cell division and epithelial morphology in spayed-hypophysectomized rats. $J$. Endocr. 56, 341-342.

Chaudhury, R.R. \& Sethi, A. (1970) Effects of an intra-uterine contraceptive device on mitosis in the rat uterus on different days of pregnancy. J. Reprod. Fert. 22, 33-40.

DAS, R.M. (1972) The effects of oestrogen on the cell cycle in epithelial and connective tissues of the mouse uterus. J. Endocr. 55, 21-30.

FinN, C.A. (1965) Oestrogen and the decidual cell reaction of implantation in mice. $J$. Endocr. 32, 223229.

FINN, C.A. (1966) Endocrine control of endometrial sensitivity during the induction of the decidual cell reaction in the mouse. $J$. Endocr. 36, 239-248.

FINN, C.A. (1971) The biology of decidual cells. $A d v$. Reprod. Physiol. 5, 1-26.

FinN, C.A. \& MARTIN, L. (1967) Patterns of cell division in the mouse uterus during early pregnancy. $J$. Endocr. 39, 593-597.

FinN, C.A. \& MARTin, L. (1969) Hormone secretion during early pregnancy in the mouse. $J$. Endocr. 45, $57-65$.

FInN, C.A. \& MARTIN, L. (1972) Endocrine control of the timing of endometrial sensitivity to a decidual stimulus. Biol. Reprod. 7, 82-86.

GalASSI, L. (1968) Autoradiographic study of the decidual cell reaction in the rat. Devl Biol. 17, 75-84.

KREHBIEL, R.H. (1937) Cytological studies of the decidual reaction in the rat during early pregnancy and in the production of deciduomata. Physiol. Zoöl. 10, 212234.

LEROY, F. (1974) Étude fonctionnelle de l'acide désoxyribonucléique dans l'endomètre du rongeur analyse morphologique semi-quantitative. Editions Arscia, Brussels.

LeRoy, F. \& GalAND, P. (1969) Radioautographic evaluation of mitotic parameters in the endometrium during the uterine sensitivity period in the pseudopregnant rat. Fert. Steril. 20, 980-992.

Lobel, B.L., Levy, E. \& Shelesnyak, M.C. (1967) Studies on the mechanism of nidation. XXXIV. Dynamics of cellular interactions during progestation and implantation in the rat. Acta endocr., Copenh., Suppl. 123, 7-109.

Marcus, G.J. (1974) Mitosis in the rat uterus during the estrous cycle, early pregnancy and early pseudopregnancy. Biol. Reprod. 10, 447-452.

Martin, L. \& FinN, C.A. (1968) Hormonal regulation of cell division in epithelial and connective tissues of the mouse uterus. J. Endocr. 41, 363-371.

Martin, L., Finn, C.A. \& Trinder, G. (1973) DNA synthesis in the endometrium of progesterone-treated mice. J. Endocr. 56, 303-307.

TACHI, C., TACHI, S. \& LindneR, H.R. (1972) Modification by progesterone oestradiol-induced cell proliferation, RNA synthesis and oestradiol distribution in the rat uterus. $J$. Reprod. Fert. 31, 59-76.

Zhinkin, L.N. \& Samoshkina, N.A. (1967) DNA synthesis and cell proliferation during formation of deciduomata in mice. J. Embryol. exp. Morph. 17, 593-603.

Received 15 November 1977

\section{EXPLANATION OF PLATES}

\section{Plate 1}

Fig. 1. Autoradiograph of a transverse section through a treated uterine horn $10 \mathrm{~h}$ after stimulation with oil : the stroma is oedematous. $\mathrm{H} \& \mathrm{E}, \times 100$.

Fig. 2. Autoradiograph of a transverse section through a control uterine horn $10 \mathrm{~h}$ after the intraluminal application of arachis oil to the contralateral horn. $H \& E, \times 100$.

Fig. 3. High-power view of Fig. 1 showing enlargement of nuclei of antimesometrial periluminal stromal cells; none are incorporating $\left[{ }^{3} \mathrm{H}\right.$ ]thymidine. The topmost cells are luminal epithelial cells. $\mathrm{H} \& \mathrm{E}, \times 500$.

Fig. 4. High-power view of Fig. 2 showing antimesometrial periluminal stromal cells. The topmost cells are luminal epithelial cells. $\mathrm{H} \& \mathrm{E}, \times 500$.

\section{Plate 2}

Fig. 5. Autoradiograph of a transverse section through a treated uterine horn $15 \mathrm{~h}$ after stimulation with oil. The oil droplet has dissolved leaving an almost circular chamber in the antimesometrial lumen. $\mathrm{H} \& \mathrm{E}, \times 100$. Fig. 6. High-power view of Fig. 5 showing the large numbers of stromal cells incorporating $\left[{ }^{3} \mathrm{H}\right]$ thymidine. The topmost cells are luminal epithelial cells. H \& E, $\times 500$.

Fig. 7. Autoradiograph of a transverse section through a decidualizing region of a treated uterine horn $20 \mathrm{~h}$ after stimulation with oil. The mouse was given colcemid $17 \cdot 5 \mathrm{~h}$ after stimulation. The inner primary zone is well developed and free of mitotic figures, and is surrounded by a band of tissue containing numerous arrested mitotic figures. $\mathrm{H} \& \mathrm{E}, \times 50$.

Fig. 8. High-power view of an autoradiograph of a transverse section through the primary decidual zone of a treated horn $20 \mathrm{~h}$ after stimulation. The stromal cells have differentiated into large decidual cells rich in cytoplasm, but are still incorporating $\left[{ }^{3} \mathrm{H}\right]$ thymidine. $\mathrm{H} \& \mathrm{E}, \times 500$. 
PLATE 1
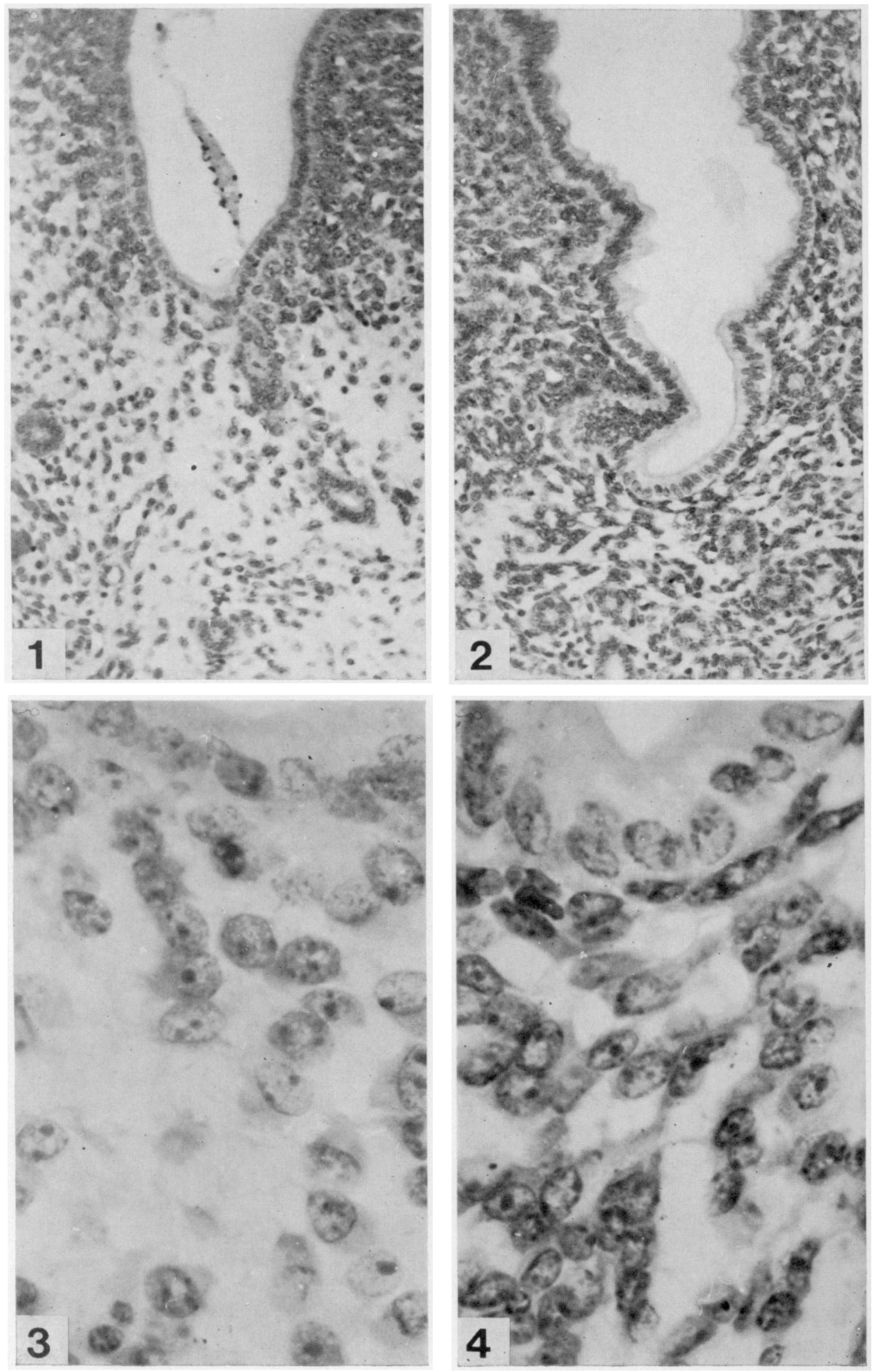
PLATE 2
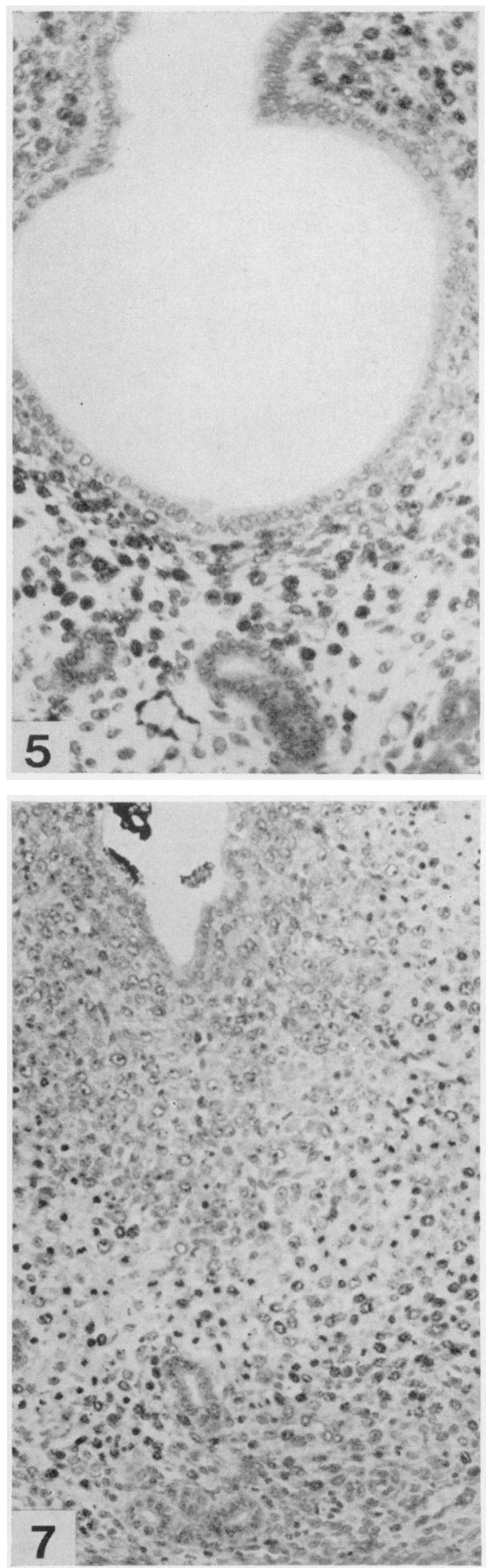
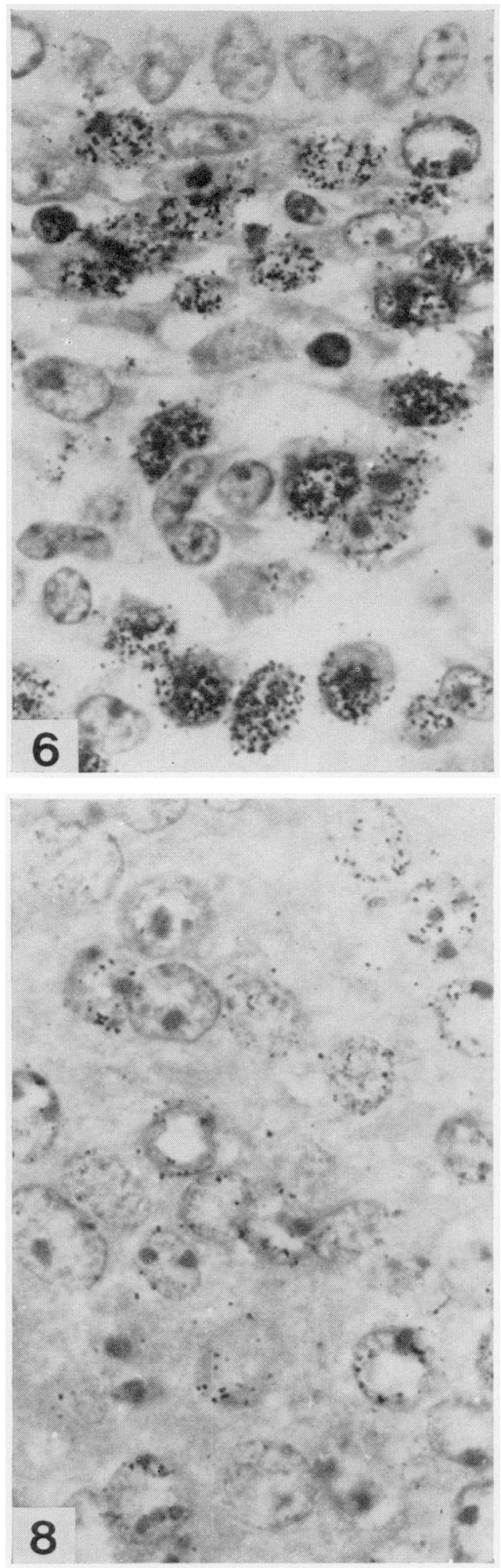